\title{
The Impact of Financial Development On The Clean Energy Transition In MENA Region: The Role of Institutional And Political Factors.
}

Haifa Saadaoui ( $\sim$ haifa.saadaoui@yahoo.fr)

University of Sfax https://orcid.org/0000-0002-7218-2291

\section{Research Article}

Keywords: Financial development, institutional quality, MENA, renewable energy transition

Posted Date: December 3rd, 2021

DOI: https://doi.org/10.21203/rs.3.rs-1090260/v1

License: (c) (1) This work is licensed under a Creative Commons Attribution 4.0 International License.

Read Full License 


\section{Abstract}

This study focuses on the role of institutional factors as well as financial development in renewable energy transition in Middle East and North Africa (MENA) region over the period 1990-2018 using the ARDL PMG method. The investigation of long-run and short-run analysis confirms that institutional and political factors play a key role in promoting the transition to renewable energy, and shows that improving these factors can lead to decarbonization of the energy sector in the long run. Another important finding is that global financial development does not have a significant effect on the transition process in the long run, implying that the whole financial system needs a fundamental structural change to accelerate the substitution between polluting and clean energies. However, in the short term, the impact appears to be negative and significant, highlighting the inadequacy of financial institutions and financial markets in promoting the region's sustainable path. Moreover, income drives the transition to renewable energy in both short and long term.

The causality results show that both financial development and institutional quality lead to renewable energy transition, while there is a bidirectional link between income and renewable energy.

This study can provide a very useful recommendation to promote a clean transition in the MENA region.

\section{Introduction}

In recent centuries, climate change and the massive exploitation of resources have become the focus of public attention worldwide. These phenomena are exerting increasing pressure on ecosystems and human beings. In fact, high consumption of hydrocarbons drives greenhouse gas (GHG) emissions, which are the main cause of global warming [Intergovernmental Panel on Climate Change (IPCC), 2014]. According to the latest report of the Renewable Energy Policy Network for the 21 st Century (REN 21, 2021), energy demand is characterized by the dominance of fossil fuels as the main source of GHGs.

It is therefore clear that the transition to a low-carbon mode of production is necessary. More specifically, decarbonizing the economy through the transition to clean energy is an attractive option. This strategy can help mitigate the negative effects of climate change by reducing carbon emissions $\left(\mathrm{CO}_{2}\right)$ into the atmosphere. It also enables to strength economic development as it helps to protect the economy from energy poverty and improve access to electricity (Sardorsky, 2021).

The growing global interest in the energy transition has been exacerbated by international negotiations on climate change. The 2015 Paris Agreement was a notable point in these international consensuses. Article 2 of the universal legal climate agreement (adopted by the 21st Conference of the Parties to the United Nations Framework Convention on Climate Change COP 21) emphasizes the urgency of reducing global warming to "well below $2^{\circ} \mathrm{C}$ ", a $4^{\circ} \mathrm{C}$ decrease from the current situation. Achieving this global goal will require significant international efforts. 
In general, the energy transition is considered as a gradual substitution between two types of energy, where the cumulative effect of some measures led to important results after a certain time. Therefore, the energy system to be introduced cannot be radically and suddenly transformed. Energy transitions take time, sometimes centuries, as shown by the experience of switching from wood to coal or from coal to oil. The slow pace of the transition process is also justified by the scale and complexity involved in major conversions, and by the tendency for new systems to face "lock-in" or "path dependency" from existing systems (Sovacool, 2016).

The report of International Renewable Energy Agency (IRENA, 2018) also states that even if an energy transition is technically feasible and economically beneficial, it will not automatically be realized.

Therefore, there is an urgent need for policymakers to take action to move from the current energy system to a more sustainable path.

Although developed countries are leading the way in converting their energy systems to a sustainable development path, this strategy has spread around the world. Developing countries have also joined this initiative. In practice, the speed of the energy transition for these countries is leisurely and timeconsuming.

This is not surprising as this time delay mainly due to the lack of financial resources to promote innovation, persistent corruption, political instability in some countries and also easy access to some types of fossil fuels.

This situation, characteristic of developing countries, can be illustrated by the example of the Middle East and North Africa (MENA) region. This group of countries is considered a promising region for the energy transition, as it has significant renewable energy potential (Aghahosseini et al., 2020).

This is an advantage in addressing the ongoing challenges and is also a means of protecting against GHG emissions (Bhutto et al., 2014). However, according to IRENA (2019), renewable energy accounts for only $6 \%$ of the installed electricity capacity in the region.

More specifically, the MENA region is rich in fossil fuels and is considered the world's largest supplier of oil and gas (Saidi et al.2020). For oil importing-countries in this region, reducing oil imports is an important issue to cope with threats associated with price volatility, as the instability of oil prices negatively affects their economic performance. Therefore, the transition to clean energy will reduce the oil dependence of non-exporting countries (Atalay et al., 2016). It can also provide an alternative source of electricity, especially as MENA countries have experienced rapid population growth, increasing demand for electricity and limited investment in new generation capacity in recent years (Saidi et al., 2020). However, the MENA region has been witnessed a political movement referred to as "Arab Spring". These riots refer to a series of anti-government protests, pro-democracy uprisings and armed rebellions against the existing political regimes in several MENA countries. It is worth noting that these movements began in Tunisia in early 2011 and quickly spread to other Arab countries such as Egypt, Libya, Syria, etc. The results of these revolutions have led to political changes. In Tunisia, for example, there was a change of 
government in 2014, the creation of a new legal framework and the introduction of new policies and new regulations.

It is important to note that these movements still have an impact on the overall economic situation and affecting institutional quality in MENA countries.

As a result, efforts to achieve renewable energy development goals may come derived in this context. For instance, Mrabet et al. (2021) point out that maintaining political stability is crucial to avoid delays in achieving environmental goals in this region.

The main objective of this article is to analyze the capacity of MENA countries to achieve a low-carbon energy transition and to examine the drivers of this transition. In particular, we focus on the importance and role of good governance, institutional quality and the role of the global financial system in this transition process. To this end, we use the ARDL panel PMG and the Pairwise Dumitrescu-Hurlin panel causality tests for the period 1990 to 2018 for 9 countries in the MENA region.

We strongly believe that the MENA region is an interesting case study to investigate the determinants of the transition to renewable energy. First, this region is intensifying its efforts towards of sustainable development. Indeed, the application of sustainable development is becoming increasingly urgent (Ben Cheikh, and Ben Zaied, 2021). The need to apply a sustainable economic model based on environmental protection and clean energy is a strategic objective for this region.

Second, this region has made significant efforts to advance renewable energy. For instance, the IRENA (2019) classifies countries such as Morocco and others as making great efforts to transition to renewable energy despite growing institutional instability.

Third, understanding the relationship between corruption, law and order, bureaucratic quality, democratic accountability, stability of government and green energy is crucial in MENA countries characterized by a high degradations in political and institutional factors.

Fourth, we can consider this study as the first to examine the global impact of the financial development system on the transition to renewable energy in MENA. Compared to the work of Belaid et al. (2021), analyzing the impact of domestic credit to the private sector, this study points to a general index of financial development. This index includes nine indicators that summarize the level of development of financial institutions and markets in terms of depth, access and efficiency. This provides a more reliable assessment of the relationship between financial development and the renewable energy transition.

The rest of the article is organized as follows: Section 2 contains the literature review. Section 3 presents the model specification and data description. Results and discussion are highlighted in Section 4; finally, conclusions and policy implications are drawn in Section 5.

\section{Literature Review}


The determinants of renewable energy consumption have fueled the debate in the empirical literature as they provide relevant policy recommendations that offer viable solutions to environmental problems and achieve the goals set out in the Paris Climate Agreement (Bourcet, 2020). It should be noted that the causal links between renewable energy and economic growth have been well explained in the economic literature. In fact, there are four relevant hypotheses that design the possible links. The first hypothesis is the growth hypothesis, which assumes a unidirectional cause-effect relationship between renewable energy and economic growth. This explains that the integration of renewable energies into the production process as a complementary factor to labor and capital can directly and indirectly influences economic growth. This hypothesis is supported by several works such as Dogan (2015), and Gozgor (2018).

The second hypothesis is the conservation hypothesis, which proves the existence of unidirectional causality between economic growth and renewable energy consumption. This means that economic growth has a direct effect on renewable energy consumption. This link may even be positive, i.e. economic growth may promote the renewable energy development. On the other hand, it is possible that the effect is negative due to a lack of developed infrastructure or good resource management, a growing economy encounters inefficiencies, and a decrease in demand for goods and services, including energy consumption. This hypothesis is tested in the following paper: Sardosky (2009), and Tugcu and Tiwari (2016).

As for the third hypothesis, it supports the bidirectional direction between the two variables. This relationship is confirmed in the following work: Kahia et al. (2017), Eren et al (2019), and Acheampong et al. (2021).

The last assumption supports neutrality between economic growth and renewable energy. This implies that the consumption of renewable energy has no effect on economic growth, and moves towards it. In other words, energy policy (expansionary or conservative) has no impact on economic growth, and this is equivalent for economic policy.

This hypothesis is supported by the work of, Menegaki (2011), Ben Jebli and Ben Youssef (2015), and Bhattacharya et al. (2016).

On the other hand, Sadorsky (2009) shows that economic growth and environmental factors are the main drivers of renewable energy demand in G7 countries over the period 1980-2005. Also, Apergis and Payne (2010), Salim and Rafiq (2012) and Silva et al. (2018) investigated this relationship in different samples, with different time periods and econometric methods to focus on the role of economic growth in the renewable energy diffusion.

In fact, the relationship between economic growth and renewable energy is critical, however there is a growing body of empirical work that focuses on the respective roles of institutional quality, good governance, and financial development in accelerating the clean energy transition.

\subsection{The influence of financial development on the transition to renewable energies}


Financial development has garnered attention in the current economic literature as a key factor on environment quality. In this regard, several articles have explored the impact of financial development on the level of $\mathrm{CO}_{2}$ emissions. See for example, Shahbaz et al. (2013) for the case of Malaysia; Abbasi and Riaz (2016) for the case of Pakistan; Gokmenoglu et al. (2021) for the case of Turkey ; Khan et al.(2021) for the case of 184 countries, etc.

Furthermore, the role of financial development in the diffusion of the renewable energies has triggered a current debate, which stresses the importance of reformulating this system in order to finance sustainable development.

In general, investments in renewable energy projects are associated with high costs related to high startup costs, long-term debt repayment costs, and ongoing investment costs for research and development (Eren et al., 2019). The role of the financial system in the renewable energy sector is to facilitate lending. Therefore, the growth of renewable energy projects can be associated with the financial development of the country.

Kim and Park (2018) show that the use of the Clean Development Mechanism can play an important role in improving access to financing for renewable energy projects.

They empirically investigated the link between the clean development mechanisms on renewable energy projects based on panel data for 64 countries with different levels of financial development.

They noted the positive effect of these mechanisms on renewable energy deployment in countries with a less developed domestic financial market. They explained this by the difficulties in financing renewable energy projects through debt or equities, especially in less developed financial markets.

According to Best (2017), financial capital stimulates the transition to more capital-intensive types of energy, in the case of renewable energy. Best (2017) draws on a sample of 137 countries over the period 1998-2013, and the results reveal that the transition to more capital-intensive power generation systems is more accessible to countries with large financial capital

Empirical studies on the relationships between financial development and renewable energy offers an inconclusive results.

For instance, Kim and Park (2016) explored the relationship between financial market development and renewable energy growth in a sample of 30 countries between 2000 and 2013.

These authors found that these effects are generally larger in countries with well-developed financial markets.

Lin et al. (2016) investigated the factors affecting renewable electricity consumption in China from 1980 to 2011 by using the Johansen cointegration technique and the vector error correction model. They found that financial development favors renewable electricity consumption. Ji and Zhang (2019) confirmed this 
result for the same case study. They even pointed out that financial development is crucial factor for the growth of renewable energy in China. It contributes $42.42 \%$ to the growth fluctuation of renewable energy, knowing that the capital market is the most important factor in this context.

Le et al. (2020) also studied this relationship using panel data from 55 countries for the period between 2005 and 2014. The conclusion of this study is similar to that of Kim and Park (2016). In particular, they showed that financial development is substantial for the development of the renewable energy sector in high-income countries. In contrast, this impact seems to be insignificant for low and middle income countries.

On the other hand, Raza et al. (2020) investigated the non-linear relationship between financial development and renewable energy consumption in major renewable energy consuming countries using the Panel Smooth Transition Regression (PSTR) model with two regimes over the period 1997-2017. The results suggest that all financial development indicators improve renewable energy penetration, but this influence is heterogeneous.

Qamruzzaman, Jianguo (2020) analyze the effect of financial development on renewable energy consumption by applying a nonlinear distributed autoregressive panel estimation method from 1990 to 2017. The positive shock effect of renewable energy has a positive long-run impact, so the effect of a negative shock has a positive impact, except in the case of the upper-middle income panel. The results long-run causality with the System-GMM specification in the error correction model revealed a bidirectional causality between renewable energy and financial development.

Ankrah and Lin (2020) examined the link between financial development and renewable energy electricity consumption in Ghana for the period 1980-2015 using Vector Error Correction Model. They found that financial development has a negative and significant effect on renewable electricity consumption.

The other hand, Alsagr and Hemmen (2021) examined this link in the case of emerging economies for the period between 1996 and 2015 via the two-step system GMM. The result shows that that financial development drives renewable energy consumption.

As well, Shahbaz et al. (2021) analyzed the impact of financial development on renewable energy transition for a sample of 34 developing countries during the period 1994 to 2015 using a Fully-Modified OLS (FMOLS) approach. The empirical results show that financial development increases the demand for renewable energy. For their part Belaid et al. (2021) confirmed the importance of financial development in enhancing the green energy production in the context of MENA countries.

Likewise, Lahiani et al. (2021) examined the influence of financial development on renewable energy consumption in the United States from 1975Q1 to 2019Q4 using the nonlinear ARDL model. The specificity of this work is the use of three measures of financial development, namely the global financial development index, the banking financial development index, and the stock market financial development 
index. The global index and stock market index have a significant short-term impact on renewable energy consumption. On the contrary, the banking index has no impact on renewable energy consumption.

\subsection{The influence of political and institutional factors on renewable energy transition}

Indeed, recent studies highlight the important role of institutional and political factors on economic growth ( see Saidi et al., 2019 for MENA countries), and on environment quality ( see Abid, 2017; Ali et al., 2019; Mahmoud et al., 2021), although, there are few studies that examine the impact of institutional and political variables on renewable energy consumption (Uzar,2020).

Some studies focused on the MENA countries. For instance Bellakhal et al. (2019) studied the link between governance, trade openness, and renewable energy investment in the 15 MENA countries using panel data between 1996-2013. Their results show that high institutional quality is associated with renewable energy investment. Moreover, this relationship seems to depend on trade governance. Indeed, poor governance in relatively open economies is less detrimental to renewable energy investment. Similarly, trade has a stronger positive effect on renewable energy investment between countries with poor institutions than between countries with good institutions. More recently, Belaid et al. (2021) examined the determinants of renewable energy production for 9 MENA countries over the period 19842014 , using a panel quantile regression model with a non-additive fixed effect. The results show that the effect of political stability is heterogeneous and confirm that political stability favors investment in the renewable energy sector.

On the other hand, some other studies adopted different data sample. For instance, Cardoret and Padovano (2016) analyzed the relationship between political factors and renewable energy deployment in a sample of European countries with a target of $20 \%$ renewable energy in the energy mix by 2020 . The results show that industry lobbying hinders the diffusion of renewable energy. Another important finding from this work is that the quality of government positively influences the transition to renewable energy. Mehara et al. (2015) investigated the key determinants of renewable energy transition in Economic Cooperation Organization (ECO) countries over the period 1992-2011 using Bayesian Model Averaging (BMA) and Weighted-Average Least Square (WALS). The results show that improvement in institutional quality can lead to improvement in renewable energy penetration in this context.

Moreover, Wu and Broadstock (2015) explored the possible relationships between financial development, institutional quality and renewable energy consumption. They selected a sample of 22 emerging economies for the period 1990-2010 using dynamic panel model estimation techniques. The results show that financial development and institutional quality have a positive influence on renewable energy consumption. On the other hand, Chang and Wang (2017) suggest the establishment of an institutional framework in China that can facilitate relevant laws and legislative proposals to define a legal perspective for better development of marine renewable energy. The authors conclude that the Chinese government should optimize the administrative system, strengthen financial regulations such as taxation, and focus on sustainable development.

In addition, Uzar (2020) analyzed the relationship between renewable energy and institutional quality 
institutional quality in 38 countries from 1990 to 2015 using the method ARDL-PMG. Economic growth and $\mathrm{CO}_{2}$ emissions are included as control variables in the model. The results of this study suggest that institutional quality positively affects renewable energy consumption in the long run. Moreover, $\mathrm{CO}_{2}$ emissions are a positive and significant determinant of renewable energy consumption. However, economic growth has a negative impact on renewable energy. In this context, institutional quality is an important strategic choice to promote renewable energy use and solve environmental problems.

\section{The Study Method}

\subsection{Data description}

This empirical analysis is based on annual series covering the period from 1990 to 2018 for 9 MENA countries (Tunisia, Morocco, Algeria, Iran, Turkey, Lebanon, Sudan, Egypt and Jordan). The selection is limited due to the unavailability of some data. The dataset includes the variables of renewable energy consumption, institutional quality, economic growth, and financial development.

Clean energy is measured by total renewable energy consumption in kilotons equivalent (Ktoe). Institutional quality is composed of five indicators measured using principal component analysis (PCA) in log. According to Uzar (2020), this variable includes corruption, law and order, bureaucratic quality, democratic accountability and stability of government. This new measure provides more information on institutional quality and political factors. Indeed, the aggregate use of the different measures gives a more accurate effect than an isolated variable. On the other hand, financial development in our study is measured by the overall financial development index published by the International Monetary Fund (IMF) (Svirydzenka, 2017). This index includes nine indices that reflect the depth, access and efficiency of development of both financial institutions and markets. This measure is better able to capture the full development of the financial sector. Data on GDP per capita (constant 2010 US\$) come from the World Bank's World Development Indicators. This variable measures the economic level of the country.

Table 1 illustrates the descriptive statistics for the natural logarithm form of institutional quality, financial development income and renewable energy in MENA countries from 1990 to 2018. All variables used in our model are negatively skewed except for income, meaning that they have longer right tails than a normal distribution. Moreover, all variables have a Platykurich distribution, as their kurtosis is lower than that of a normal distribution. Finally, the Jarque-Bera test for normality shows that only income and institutional quality are normally distributed. 
Table 1

Descriptive statistics

\begin{tabular}{|lllll|}
\hline & LnRE & InIQ & InGDP & InFD \\
\hline Mean & 6.345 & 0.128 & 24.815 & -1.401 \\
\hline Maximum & 8.948 & 2.547 & 27.587 & -0.528 \\
\hline Minimum & 1.791 & -2.821 & 21.766 & -2.986 \\
\hline Std. dev. & 1.77 & 0.896 & 1.265 & 0.545 \\
\hline Skewness & -0.209 & -0.177 & 0.150 & -0.733 \\
\hline Kurtosis & 2.120 & 2.663 & 2.524 & 2.974 \\
\hline Jarque-Bera & 10.323 & 2.601 & 3.451 & 23.427 \\
& {$[0.005732]$} & {$[0.272278]$} & {$[0.178074]$} & {$[0.000008]$} \\
\hline Note: $p$-values are in [ & & & \\
\hline
\end{tabular}

\subsection{Model Specification}

In line with the recent literature on the determinants of renewable energy, we develop an empirical model (equation 1) that takes into account the impact of financial development (FD), institutional quality (IQ), and economic growth (GDP) on renewable energy consumption (RE).

$$
R E=f(I Q, F D, G D P)
$$

By applying the logarithmic form, the equation (1) can be designated as follows:

$$
\ln R E_{i t}=\beta_{0}+\beta_{1} \ln I Q_{i t}+\beta_{2} \ln F D_{i t}+\beta_{3} \ln G D P_{i t}+\mu_{t}
$$

where $\mathrm{i}$ is the country-specific dimension ( $\mathrm{i} .=9$ countries), and $\mathrm{t}$ is the estimated time periods $(\mathrm{t}=1990$, $1991, \ldots, 2018) . \mu_{t}$ represents the error term that is identically and independently distributed (iiid $\sim \mathrm{N}(\mu$, $\sigma)$ ).

In this study, we use the ARDL-PMG proposed by Pesaran et al. (1999) to examine the long and short term in the model. For small $t$ and finite sample sizes, the ARDL model is considered to be the relatively most efficient model (Mongo et al, 2021).

ARDL ( $p, q, \ldots, q)$ model proposed by Pesaran et al. (1999) can be expressed as follows: 
$R E_{i t}=\sum_{j=1}^{p} w_{i j} R E_{i, t-j}+\sum_{j=1}^{p-1} \theta_{i j} \Delta X_{i, t-j}+\gamma_{i}+\varepsilon_{i t}$

Where, $\mathrm{X}$ represents the vector independent variables.

Then equation 3 can be written as follow:

$$
\Delta \operatorname{lnR} E_{i t}=\delta_{i}\left(\operatorname{lnRE} E_{i, t-1}-\beta_{i} X_{i t} \sum_{j=1}^{p} w_{i j} R E_{i, t-j}+\sum_{j=1}^{p-1} \theta_{i j} \Delta X_{i, t-j}+\gamma_{i}+\varepsilon_{i t}\right.
$$

\section{Empirical Results And Analysis}

\subsection{Preliminary tests}

The first step in our analysis is to examine cross-country dependence. Indeed, many studies have ignored this crucial step, which may lead to biased results. For this reason, we test for cross-country dependence in our study using the Breusch-Pagan LM (1980) and the Pesaran CD (2004). The use of these two tests is preferred in panel data models for cross-sectional dependence.

Table 2 presents the main results concerning cross sectional dependence. The null hypothesis for the Breusch-Pagan LM (1980) and Pesaran CD (2004) tests is the absence of cross-sectional dependence. The null hypothesis is rejected for all series at the $1 \%$ significance level. This result implies that crosssectional dependence exists for all series in the model.

Table 2: Cross-sectional dependence tests

\begin{tabular}{|lllll|}
\hline & InRE & InIQ & InGDP & InFD \\
\hline Breusch-Pagan LM & 498.5410 & 391.0708 & 912.2782 & 364.7283 \\
& $(0.0000)$ & $(0.0000)$ & $(0.0000)$ & $(0.0000)$ \\
\hline Pesaran CD & 8.484599 & 18.47772 & 30.17518 & 9.930230 \\
& $(0.0000)$ & $(0.0000)$ & $(0.0000)$ & $(0.0000)$ \\
\hline
\end{tabular}

Note: $p$-values are in ().

The next step is to analyze the order of integration. For this we use the first and second generation stationarity tests. Table 3 illustrates the results of the stationarity tests for the first and second generation. We use the first generation tests: the unit root tests of Levin et al. (2002) and Im et al. (2003). The null hypothesis of these two tests is that the series have a unit root. The results of the previous two tests yielded the same results. More specifically, the results of the LLC unit root test and IPS indicate that 
the null hypothesis for LnIQ and LnGDP is rejected at the level. However, when these tests are applied at the first difference level, the null hypothesis of non-stationarity is rejected for all models. Therefore, the first generation tests show that InRE and InFD are I(1) and InGDP and LnIQ are I(0). In our case, the presence of cross-sectional dependence in the panel data recommends the use of second generation panel unit root tests. Accordingly, the results obtained with the first generation tests can be considered unreliable. Therefore, we use the second generation CADF unit root test developed by Pesaran (2007). The results of the CADF test prove the same order of integration.

The stationarity results show that all variables are integrated in order or first difference, and none of them is I (2), which allows us to use the ARDL model.

\section{Table 3 : Unit root results}

\begin{tabular}{|c|c|c|c|c|c|c|}
\hline & LLC & & IPS & & CADF & \\
\hline variables & Level & $\begin{array}{l}\text { First } \\
\text { difference }\end{array}$ & Level & $\begin{array}{l}\text { First } \\
\text { difference }\end{array}$ & Level & $\begin{array}{l}\text { First } \\
\text { difference }\end{array}$ \\
\hline LnRE & -0.844 & $-7.210 *$ & 1.553 & $-7.159 *$ & -0.493 & $-3.602^{\star}$ \\
\hline InIQ & $-3.138^{*}$ & $-8.860 *$ & $-3.304 *$ & $-9.080 *$ & $-3.112^{\star}$ & $-4.886^{\star}$ \\
\hline InGDP & $-1.692^{\star *}$ & $-2.474^{\star}$ & 1.820 & $-2.728 *$ & $-3.145^{\star}$ & $-3.850 *$ \\
\hline InFD & -0.77865 & $-6.33033^{\star}$ & -1.00028 & $-7.26717^{\star}$ & -2.027 & $-3.698^{\star}$ \\
\hline
\end{tabular}

Note:*, ** show the significance level of $1 \%$, and $5 \%$, respectively.

We then examine the presence of cointegration between variables using the Westerlund panel cointegration test proposed by Westerlund (2007). The advantage of this test is its ability to deal with dependent cross-sectional data. Westerlund's panel cointegration test developed 4 different statistical tests based on the ECM to overcome the weaknesses of the other tests. The group mean tests (Gt and $\mathrm{Ga}$ ) examine the hypothesis that at least one unit is cointegrated, while the panel tests ( $\mathrm{Pt}$ and $\mathrm{Pa}$ ) focus on the alternative hypothesis that the panel is cointegrated.

The results of the cointegration tests are reported in Table 4. The Pt and Pa tests reject the null hypothesis of no cointegration at the $1 \%$ significance level. Thus, our result confirms that there is cointegration in at least one unit.

\section{Table 4: Westerlund cointegration test.}




\begin{tabular}{|llll|}
\hline statistic & value & Z-value & P-value \\
\hline $\mathrm{Gt}$ & -1.106 & 1.766 & 0.961 \\
$\mathrm{Ga}$ & -3.607 & 2.019 & 0.978 \\
$\mathrm{Pt}$ & -9.769 & -4.439 & $0.000 *$ \\
\hline $\mathrm{Pa}$ & -9.265 & -2.373 & $0.009 *$ \\
\hline
\end{tabular}

\subsection{ARDL results}

We use the Pooled Mean Group (PMG) to estimate the long-run and short-run equilibrium between financial development, institutional quality, income, and renewable energy consumption. Table 5 illustrates the results for the PMG model.

\section{Table 5: the ARDL analysis}

\begin{tabular}{|c|c|c|c|c|}
\hline \multicolumn{2}{|c|}{ Long term equation } & \multirow[b]{2}{*}{ Std. Err. } & \multirow[b]{2}{*}{ P-value } & \multirow{2}{*}{ 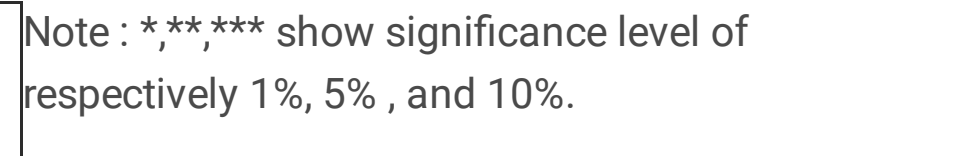 } \\
\hline Variables & coefficients & & & \\
\hline InIQ & $0.098 *$ & 0.030 & 0.001 & 4.2.1. Long-run result \\
\hline InGDP & $0.343^{*}$ & 0.075 & 0.000 & In the long run, the results show that institutional \\
\hline $\operatorname{lnFD}$ & -0.227 & 0.260 & 0.381 & $\begin{array}{l}\text { quality has a positive and significant impact on the } \\
\text { transition to renewable energv. In other words, a } 1 \%\end{array}$ \\
\hline \multicolumn{2}{|c|}{ Short-term equation } & \multirow[b]{2}{*}{ Std. Err. } & \multirow[b]{2}{*}{ P-value } & increase in institutional quality leads to a $0.098 \%$ \\
\hline Variables & Coefficient & & & increase in renewable energy diffusion in MENA \\
\hline ECT & $-0.092^{\star \star *}$ & 0.0527 & 0.078 & \multirow{6}{*}{$\begin{array}{l}\text { countries at a 1\% significance level. } \\
\text { Our findings support the argument that } \\
\text { the improving in institutional and political factors } \\
\text { can console the transition to renewable energy. For } \\
\text { example, the development of democracy, control of } \\
\text { corruption, political stability, the increase of } \\
\text { bureaucratic quality and the establishment of } \\
\text { sound laws lead to the consideration of the social }\end{array}$} \\
\hline LnIQ & 0.041 & 0.042 & 0.328 & \\
\hline $\operatorname{lnGDP}$ & 0.122 ** & 0.122 & 0.044 & \\
\hline $\ln F D$ & $-0.171^{\star}$ & 0.070 & 0.015 & \\
\hline constant & $-0.285^{\star \star \star}$ & 0.1626 & 0.079 & \\
\hline & & & & \\
\hline
\end{tabular}

According to Mrabet et al. (2021), political stability is an essential condition for sustainable development in the MENA region. Moreover, the increase of conflicts in this region promotes environmental degradation (Usman et al., 2021). Bardi and Hfaiedh (2020) argue that fighting corruption improves environmental quality in MENA countries in the long run. 
Similarly, Bellakhal et al. (2019) show that renewable energy investment is associated with high institutional quality in MENA countries over the period 1996-2013. For the same region, our result is at odds with Belaid et al. (2021) who show that the impact of political stability on renewable energy production is heterogeneous over the period 1984-2014.

For other case studies, our results can be classified similarly to those of Wu and Broadstock (2015), who found a positive effect of institutional quality on the use of renewable energy for a panel of 22 developing countries over the period 1990-2010. Uzar (2020) for 38 countries between 1990 and 2015. The second result of this study states that financial development has a negative but not significant effect on renewable energy consumption. Thus, our results suggest that overall financial sector development has no real impact on the promotion of clean energy in the MENA region.

The second result of this study states that financial development has a negative but not significant impact on renewable energy consumption. Thus, our result suggests that overall financial sector development has no real impact on the promotion of clean energy in the MENA region.

This result is not surprising given that the MENA region is characterized by a limited financial system in some countries. Indeed, the degree of progress of these systems varies from country to country.

Charfedine and Kahia (2019) pointed out that the contribution of financial institutions to improving environmental quality through a small decrease in $\mathrm{CO} 2$ emissions in MENA countries is very low. They explain this result by the inability of the financial sector to improve the renewable energy sector, which is in line with our present result. Thus, this region must Therefore, make efforts to regulate the financial system to have an impact on green energy and green investments.

Our result is consistent with Lei et al. (2021) who found no significant impact of financial development on renewable energy consumption in China.

Our results are in contrast with those of Belaid et al. (2021) who found that domestic credit to the private sector has a positive impact on renewable energy production in the MENA region.

Alsag and Hemmen (2021) for emerging economies from 1996 to 2015. Shahbaz et al. (2021) for 34 developing countries from 1994 to 2015. And Lahiani et al. (2021) for the United States from 1975Q1 to 2019 Q4.

In terms of economic growth, the results show that income has a positive impact on renewable energy consumption. Therefore, an increase in income will stimulate the transition to renewable energy in MENA countries. A $1 \%$ increase in income led to $0.343 \%$ improvement in renewable energy transition at $1 \%$ significance level. The results are inconsistent with those of Cardoret and Padovano (2016), Uzar (2021), and Shahbaz et al. (2021).

\subsubsection{Short -term result}

The short-term dynamics can provide the necessary information on how adjustments are made between the different variables in the model to restore long-term equilibrium. 
It was found that the error correction term (ECT) is significant and negative, indicating the existence of a long-run relationship between the variables. This indicates a rapid adjustment towards equilibrium. The rate at which the model adjusts to the long-run equilibrium is 0.092 . Thus, the model corrects its state of disequilibrium at an adjustment rate of 0.092 per year when an exogenous shock is applied to the system

Table 5 also provides the results of the short run analysis. It is observed that institutional quality in the MENA countries has a non-significant effect on green energy. In contrast, financial development hampers the transition to renewable energy with a significant effect $(-0.171)$.

Moreover, the results show that income has a positive and significant effect on renewable energy (0.122).

\subsection{Causality test}

Table 6. Pairwise Dumitrescu-Hurlin panel causality tests

\begin{tabular}{|c|c|c|}
\hline & Zbar-Stat. & P-value \\
\hline $\mathrm{RE} \otimes>\mathrm{IQ}$ & 2.6570 & 0.3588 \\
\hline $\mathrm{IQ} \otimes>\mathrm{RE}$ & $9.3893^{*}$ & 0.0000 \\
\hline $\mathrm{RE} \otimes>\mathrm{GDP}$ & $2.5920 *$ & 0.0095 \\
\hline $\mathrm{GDP} \otimes>\mathrm{RE}$ & $3.9603^{*}$ & 0.0001 \\
\hline $\mathrm{RE} \otimes>\mathrm{FD}$ & 0.5864 & 0.5576 \\
\hline $\mathrm{FD} \otimes>\mathrm{RE}$ & $2.6570 *$ & 0.0079 \\
\hline GDP to IQ & $10.8857 *$ & 0.0000 \\
\hline $\mathrm{IQ} \otimes>\mathrm{GDP}$ & $8.3139 *$ & 0.0000 \\
\hline $\mathrm{FD} \otimes>\mathrm{GDP}$ & $10.3251^{*}$ & 0.0000 \\
\hline $\mathrm{GDP} \otimes>\mathrm{FD}$ & $2.8459 *$ & 0.0044 \\
\hline $\mathrm{FD} \otimes>\mathrm{IQ}$ & $5.3768^{*}$ & 0.0000 \\
\hline 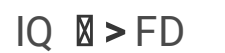 & 1.3686 & 0.1711 \\
\hline
\end{tabular}

Notes: $\mathbb{\otimes}$ : denote no causality* shows significance level of $1 \%$.

Finally, we use the Dumitrescu-Hurlin panel causality test to analyze the links that might exist between financial development, economic development, institutional quality and renewable energy diffusion. Indeed, this test proves to be robust to the SDC (Baloch et al. 2020).

The results of the panel causality test are reported in Table 6 . The results suggest that there is a unidirectional causality running from institutional quality to renewable energy. This finding implies that 
renewable energy consumption is influenced by institutional quality and political factors. This finding is consistent with that of Uzar (2020) who finds unidirectional causality between institutional quality and renewable energy.

However, our result is inconsistent with Saidi et al. (2019) who suggest that there is no causal relationship between renewable energy and five factors of institutional quality in the MENA region.

The results also show that financial development causes the transition to renewable energy at a significance level of $1 \%$. This implies that financial development can affect the transition to renewable energy, but not vice versa. Our results are in line with Lin et al. (2016) in China, who found evidence for the unidirectional hypothesis from financial development to renewable electricity.

As far as the relationship renewable energy and income is concerned, the results suggest that there is a bidirectional causality between the aforementioned variables. The result is consistent with the findings of Apergis and Payne (2010); Apergis and Payne (2012); Lin and Mubarak (2014); Dogan (2016); Amri (2017); Ito (2017); Kahia et al. (2017) and Acheampong et al. (2021).

The results show that both institutional quality and financial development affect income in the MENA region and vice versa. Finally, we can find a unidirectional causality running from financial development to institutional quality.

\section{Conclusions And Policy Implications}

This paper examines the dynamic impact of three fundamental variables affecting the clean energy transition in the case of MENA countries, namely institutional and political factors, financial development, and income. The ARDL panel framework and Pairwise Dumitrescu-Hurlin panel causality tests were employed to analyze the long and short run cointegration results and causality links, in our model, respectively, using panel data for the period 1990-2018. Our study reveals several interesting results and provides clear implications for policy makers in the transition process to green energy.

First, the study found that institutional quality increases the share of renewable energy in the long run, but is insignificant in the short run. It follows that improving institutional quality and the political factors will enable MENA countries to reap to the benefits of the renewable energy sector in the long run. Moreover, the causality test confirms the previous result, it imply that institutional quality causes the renewable energy transition. This region needs significant institutional reforms that will bring about real and consistent changes in the fight against corruption. Therefore, implementing anti-corruption measures, reducing the power of lobbyists, improving political stability, reducing bureaucracy, improving democratic quality, and protecting property rights are crucial to promoting clean energy investment and facilitating substitution between polluting and clean energy in MENA countries.

Second, regarding financial development, our results have shown that the overall index of financial development has negative impact on the diffusion of renewable energy in the short run. However, in the 
long run, financial development demonstrates a non-significant influence on clean energy. This result is in contrast to Belaid et al. (2021) in the context of the MENA region, who suggest that credit to private as an indicator of financial development boosts the transition to renewable energy.

Our result shows that the financial system as a whole does not facilitate the clean transition. This means that the financial system is still not structured well enough to incentivize investors in green projects. It still allows for the development of environmentally damaging projects. This result provides a clear idea for policy makers in this region to introduce new financial mechanisms to facilitate the financing of modern projects, especially environmentally friendly projects. As Kim and Park (2018) have shown, the nondeveloped financial system needs to introduce clean financing mechanisms to promote substitution between renewable and non- renewable energy. Moreover, the causality results reported evidence suggesting that financial development causes renewable energy consumption.

Policymakers in the MENA region need to implement financial, monetary, and environmental policies through legislation to encourage the development of financial systems to support clean energy investments. In this regard, governments in these countries should provide incentives to support the establishment of financial institutions that meet regional and national sustainability criteria. In particular, it is important that the policymakers encourages the creation of green funds.

Third, income was found to boost renewable energy consumption in MENA countries in both the short and long term. The improvement in economic activities can increase the demand for renewable energy. The causality analysis found that there is a bidirectional causal relationship between renewable energy and economic growth. This hypothesis states that economic growth encourages the use of renewable energy. Indeed, higher economic growth generates funds for renewable energy investment, and similar strong clean energy penetration promotes economic growth. Thus, the MENA region needs to implement effective strategies to promote the transition to renewable energy in order to harness its clean energy potential. These strategies are based on strengthening energy efficiency strategies and increasing R\&D spending on renewable energy technologies.

Future research also needs to focus on the role of technological innovation and ICT factors to explore their potential impact on decarbonizing the economy in the MENA region.

\section{Declarations}

Funding: Not applicable

Conflicts of interest/Competing interests: Not applicable

Availability of data and materials: All data is provided in full in the results section of this manuscript.

Ethics approval: Not applicable

Consent to participate: Not applicable 
Consent for publication: Not applicable

Acknowledgements: Not applicable

\section{References}

1. Abbasi F, Riaz K (2016) CO2 emissions and financial development in an emerging economy: An augmented VAR approach. Energy Policy 90:102-114. https://doi.org/10.1016/j.enpol.2015.12.017

2. Abid M (2017) Does economic, financial and institutional developments matter for environmental quality? A comparative analysis of EU and MEA countries. J Environ Manage 188:183-194. https://doi.org/10.1016/j.jenvman.2016.12.007

3. Acheampong AO, Boateng E, Amponsah M, Dzator J (2021) Revisiting the economic growth-energy consumption nexus: Does globalization matter? Energy Econo. 102:105472. https://doi.org/10.1016/j.eneco.2021.105472

4. Aghahosseini A, Bogdanov D, Breyer C (2020) Towards sustainable development in the MENA region: Analysing the feasibility of a $100 \%$ renewable electricity system in 2030 . Energy Strategy Rev 28:100466. https://doi.org/10.1016/j.esr.2020.100466

5. Ali HS, Zeqiraj V, Lin WL, Law SH, Yusop Z, Bare UAA, Chin L (2019) Does quality institutions promote environmental quality? Environ Sci Pollut Res 26:10446-10456. https://doi.org/10.1007/s11356019-04670-9

6. Alsagr N, Hemmen VS (2021) The impact of financial development and geopolitical risk on renewable energy consumption: evidence from emerging markets. Environ Sci Pollut Res 28:2590625919. https://doi.org/10.1007/s11356-021-12447-2

7. Amri F (2017) Intercourse across economic growth, trade and renewable energy consumption in developing and developed countries. Renew Sust Energ Rev 69:527-534. https://doi.org/10.1016/j.rser.2016.11.230

8. Ankrah I, Lin B (2020) Renewable energy development in Ghana: Beyond potentials and commitment. Energy 198:117356. https://doi.org/10.1016/j.energy.2020.117356

9. Apergis N, Payne JE (2010) Renewable energy consumption and economic growth: Evidence from a panel of OECD countries. Energy Policy 38:656-660. https://doi.org/10.1016/j.enpol.2009.09.002

10. Apergis N, Payne JE (2012) Renewable and non-renewable energy consumption-growth nexus: Evidence from a panel error correction model. Energy Econ 34:733-738. https://doi.org/10.1016/j.eneco.2011.04.007

11. Atalay $Y$, Biermann F, Kalfagianni A (2016) Adoption of renewable energy technologies in oil-rich countries: Explaining policy variation in the Gulf Cooperation Council states. Renewable Energy 85:206-214. https://doi.org/10.1016/j.renene.2015.06.045

12. Baloch MA, Ozturk I, Bekun FV, Khan D (2021) Modeling the dynamic linkage between financial development, energy innovation, and environmental quality: Does globalization matter? Bus. Strategy Environ 30:176-184. https://doi.org/10.1002/bse.2615 
13. Bardi W, Hfaiedh MA (2021) Causal Interaction between FDI, Corruption and Environmental Quality in the MENA Region. Economies 9:14. https://doi.org/10.3390/economies9010014

14. Belaïd F, Elsayed AH, Omri A (2021) Key drivers of renewable energy deployment in the MENA Region: Empirical evidence using panel quantile regression. Struct Chang Econ Dyn 57:225-238. https://doi.org/10.1016/j.strueco.2021.03.011

15. Bellakhal R, Ben Kheder S, Haffoudhi H (2019) Governance and renewable energy investment in MENA countries:How does trade matter? Energy Econ 84:104541. https://doi.org/10.1016/j.eneco.2019.104541

16. Ben Cheikh N, Ben Zaied Y (2021) A new look at carbon dioxide emissions in MENA countries. Clim Change 166:27. https://doi.org/10.1007/s10584-021-03126-9

17. Ben Jebli M, Ben Youssef S (2015) The environmental Kuznets curve, economic growth, renewable and non-renewable energy, and trade in Tunisia. Renew Sust Energ Rev 47:173-185. https://doi.org/10.1016/j.rser.2015.02.049

18. Best R (2017) Switching towards coal or renewable energy? The effects of financial capital on energy transitions. Energy Econ 63:75-83. https://doi.org/10.1016/j.eneco.2017.01.019

19. Bhattacharya M, Paramati SR, Ozturk I, Bhattacharya S (2016) The effect of renewable energy consumption on economic growth: Evidence from top 38 countries. Appl Energy 162:733-741. https://doi.org/10.1016/j.apenergy.2015.10.104

20. Bhutto AW, Bazmi AA, Zahedi G, Klemeš JJ (2014) A review of progress in renewable energy implementation in the Gulf Cooperation Council countries. J Clean Prod Special Volume: PSE Asia for Cleaner Production 71:168-180. https://doi.org/10.1016/j.jclepro.2013.12.073

21. Bourcet C (2020) Empirical determinants of renewable energy deployment: A systematic literature review. Energy Econ 85:104563. https://doi.org/10.1016/j.eneco.2019.104563

22. Breusch TS, Pagan AR (1980) The Lagrange multiplier test and its applications to model specification in econometrics. Rev Econ Stud 47:239-253

23. Cadoret I, Padovano F (2016) The political drivers of renewable energies policies. Energy Econo 56:261-269. https://doi.org/10.1016/j.eneco.2016.03.003

24. Chang YC, Wang N (2017) Legal system for the development of marine renewable energy in China. Sust Energ Rev 75:192-196. https://doi.org/10.1016/j.rser.2016.10.063

25. Charfeddine L, Kahia M (2019) Impact of renewable energy consumption and financial development on $\mathrm{CO} 2$ emissions and economic growth in the MENA region: A panel vector autoregressive (PVAR) analysis. Renewable Energy 139:198-213. https://doi.org/10.1016/j.renene.2019.01.010

26. Da Silva PP, Cerqueira PA, Ogbe W (2018) Determinants of renewable energy growth in Sub-Saharan Africa: Evidence from panel ARDL. Energy 156:45-54. https://doi.org/10.1016/j.energy.2018.05.068

27. Dogan E (2015) The relationship between economic growth and electricity consumption from renewable and non-renewable sources: A study of Turkey. Renew Sust Energ Rev 52:534-546. https://doi.org/10.1016/j.rser.2015.07.130 
28. Dumitrescu El, Hurlin C (2012) Testing for Granger non-causality in heterogeneous panels. Econ Model 29:1450-1460. https://doi.org/10.1016/j.econmod.2012.02.014

29. Eren BM, Taspinar N, Gokmenoglu KK (2019) The impact of financial development and economic growth on renewable energy consumption: Empirical analysis of India. Sci Total Environ 663:189197. https://doi.org/10.1016/j.scitotenv.2019.01.323

30. Gokmenoglu KK, Taspinar N, Rahman MM (2021) Military expenditure, financial development and environmental degradation in Turkey: A comparison of $\mathrm{CO} 2$ emissions and ecological footprint. Int $\mathrm{J}$ Finance Econ 26:986-997. https://doi.org/10.1002/ijfe.1831

31. Gozgor G (2018) A new approach to the renewable energy-growth nexus: evidence from the USA. Environ Sci Pollut Res 25:16590-16600. https://doi.org/10.1007/s11356-018-1858-9

32. Im KS, Pesaran MH, Shin Y (2003) Testing for unit roots in heterogeneous panels. J Econom 115:5374

33. IPCC (2014) Climate Change 2014: Synthesis Report. Contribution of Working Groups I, II and III to the Fifth Assessment Report of the Intergovernmental Panel on Climate Change [Core Writing Team, Pachauri RK, Meyer LA (eds.)].IPCC, Geneva, Switzerland https://www.ipcc.ch/site/assets/uploads/2018/02/SYR_AR5_FINAL_full.pdf

34. IRENA (2018) Opportunities to accelerate national energy transitions through enhanced deployment of renewables (Report to the G20 Energy Transitions Working Group); International Renewable Energy Agency, Abu Dhabi

35. IRENA (2019) energy transformation middle east and north Africa. GLOBAL RENEWABLES OUTLOOK

36. Ji Q, Zhang D (2019) How much does financial development contribute to renewable energy growth and upgrading of energy structure in China? Energy Policy 128:114-124.

https://doi.org/10.1016/j.enpol.2018.12.047

37. Kahia M, Aïssa MSB, Lanouar C (2017) Renewable and non-renewable energy use - economic growth nexus: The case of MENA Net Oil Importing Countries. 71:127-140.

https://doi.org/10.1016/j.rser.2017.01.010

38. Khan S, Khan MK, Muhammad B (2021) Impact of financial development and energy consumption on environmental degradation in 184 countries using a dynamic panel model. Environ Sci Pollut Res 28:9542-9557. https://doi.org/10.1007/s11356-020-11239-4

39. Kim J, Park K (2016) Financial development and deployment of renewable energy technologies. Energy Econ 59:238-250. https://doi.org/10.1016/j.eneco.2016.08.012

40. Kim J, Park K (2018) Effect of the Clean Development Mechanism on the deployment of renewable energy: Less developed vs. well-developed financial markets. Energy Econ 75:1-13. https://doi.org/10.1016/j.eneco.2018.07.034

41. Lahiani A, Mefteh-Wali S, Shahbaz M, Vo XV (2021) Does financial development influence renewable energy consumption to achieve carbon neutrality in the USA? Energy Policy 158:112524. https://doi.org/10.1016/j.enpol.2021.112524 
42. Le TH, Nguyen CP, Park D (2020) Financing renewable energy development: Insights from 55 countries. Energy Res Soc Sci 68:101537. https://doi.org/10.1016/j.erss.2020.101537

43. Lei W, Liu L, Hafeez M, Sohail S (2021) Do economic policy uncertainty and financial development influence the renewable energy consumption levels in China? Environ Sci Pollut Res. https://doi.org/10.1007/s11356-021-16194-2

44. Levin A, Lin CF, Chu CSJ (2002) Unit root tests in panel data: asymptotic asymptotic and finitesample properties. J Econom 108:1-24

45. Lin B, Omoju OE, Okonkwo JU (2016) Factors influencing renewable electricity consumption in China. Renew Sust Energ Rev 55:687-696. https://doi.org/10.1016/j.rser.2015.11.003

46. Mahmood H, Tanveer M, Ahmad A-R, Furqan M (2021) Rule of Law and Control of Corruption in Managing CO2 Emissions Issue in Pakistan https://mpra.ub.uni-muenchen.de/109250

47. Mehrara M, Rezaei S, Razi DH (2015) Determinants of Renewable Energy Consumption among ECO Countries; Based on Bayesian Model Averaging and Weighted-Average Least Square. Int lett soc humanist sci 54:96-109

48. Menegaki AN (2011) Growth and renewable energy in Europe: A random effect model with evidence for neutrality hypothesis. Energy Econ 33:257-263. https://doi.org/10.1016/j.eneco.2010.10.004

49. Mongo M, Belaïd F, Ramdani B (2021) The effects of environmental innovations on $\mathrm{CO} 2$ emissions: Empirical evidence from Europe. Environ Sci Policy 118:1-9. https://doi.org/10.1016/j.envsci.2020.12.004

50. Mrabet Z, Alsamara M, Mimouni K, Mnasri A (2021) Can human development and political stability improve environmental quality? New evidence from the MENA region. Econ Model 94:28-44. https://doi.org/10.1016/j.econmod.2020.09.021

51. Pesaran MH (2004) General diagnostic tests for cross section dependence in panels.Work. Pap.435 (CESifo).

52. Pesaran MH (2007) A simple panel unit root test in the presence of cross-section dependence J.Appl. Econom.22,265-312

53. Pesaran MH, Shin Y, Smith RP (1999) Pooled Mean Group Estimation of Dynamic Heterogeneous Panels. J Am Stat Assoc 94:621-634. https://doi.org/10.1080/01621459.1999.10474156

54. Qamruzzaman M, Jianguo W (2020) The asymmetric relationship between financial development, trade openness, foreign capital flows, and renewable energy consumption: Fresh evidence from panel NARDL investigation. Renewable Energy 159:827-842. https://doi.org/10.1016/j.renene.2020.06.069

55. Raza SA, Shah N, Qureshi MA, Qaiser S, Ali R, Ahmed F (2020) Non-linear threshold effect of financial development on renewable energy consumption: evidence from panel smooth transition regression approach. Environ Sci Pollut Res 27:32034-32047. https://doi.org/10.1007/s11356-020-09520-7

56. REN21 (2021) Renewables 2021 Global Status Report (Paris: REN21 Secretariat). ISBN 978-3948393-03-8 
57. Sadorsky P (2009) Renewable energy consumption, CO2 emissions and oil prices in the G7 countries. Energy Econ 31:456-462. https://doi.org/10.1016/j.eneco.2008.12.010

58. Sadorsky P (2021) Wind energy for sustainable development: Driving factors and future outlook. J Clean Prod 289:125779. https://doi.org/10.1016/j.jclepro.2020.125779

59. Saidi H, El Montasser G, Ajmi AN (2020) The Role of Institutions in the Renewable Energy-Growth Nexus in the MENA Region: a Panel Cointegration Approach. Environ Model Assess 25:259-276. https://doi.org/10.1007/s10666-019-09672-y

60. Salim RA, Rafiq S (2012) Why do some emerging economies proactively accelerate the adoption of renewable energy? Energy Econn 34:1051-1057. https://doi.org/10.1016/j.eneco.2011.08.015

61. Shahbaz M, Solarin SA, Mahmood H, Arouri M (2013) Does financial development reduce CO2 emissions in Malaysian economy? A time series analysis. Econ Model 35:145-152. https://doi.org/10.1016/j.econmod.2013.06.037

62. Shahbaz M, Topcu BA, Sarıgül SS, Vo XV (2021) The effect of financial development on renewable energy demand: The case of developing countries. Renewable Energy 178:1370-1380. https://doi.org/10.1016/j.renene.2021.06.121

63. Sovacool BK (2016) How long will it take? Conceptualizing the temporal dynamics of energy transitions. Energy Research \& Social Science, Energy Transitions in Europe: Emerging Challenges, Innovative Approaches, and Possible Solutions. 13:202-215. https://doi.org/10.1016/j.erss.2015.12.020

64. Svirydzenka K (2017) Introducing a New Broad-based Index of Financial Development. Available at: https://www.imf.org/en/Publications/WP/Issues/2016/12/31/Introducing-a-New-Broad-basedIndex-of-Financial-Development-43621

65. Tugcu CT, Tiwari AK (2016) Does renewable and/or non-renewable energy consumption matter for total factor productivity (TFP) growth? Evidence from the BRICS. Renew Sust Energ Rev 65:610-616. https://doi.org/10.1016/j.rser.2016.07.016

66. Usman O, Rafindadi AA, Sarkodie SA (2021) Conflicts and ecological footprint in MENA countries: implications for sustainable terrestrial ecosystem. Environ Sci Pollut Res 28:59988-59999. https://doi.org/10.1007/s11356-021-14931-1

67. Uzar U (2020) Political economy of renewable energy: Does institutional quality make a difference in renewable energy consumption? Renewable Energy 155:591-603. https://doi.org/10.1016/j.renene.2020.03.172

68. Westerlund J (2007) Testing for Panel Cointegration with Multiple Structural Breaks. Oxf Bull Econ Stat 68:101-132. https://doi.org/10.1111/j.1468-0084.2006.00154.x

69. Wu L, Broadstock DC (2015) Does economic, financial and institutional development matter for renewable energy consumption? Evidence from emerging economies. Int J Econ Policy Emerg Econ 8:20-39. https://doi.org/10.1504/IJEPEE.2015.068246 